\title{
PROPERTY, PRIORITY AND APPORTIONMENT: THE CASE OF THE ACQUISITION CREDITOR
}

\author{
ARUNA NAIR ${ }^{*}$
}

\section{INTRODUCTION}

In Abbey National Building Society $v$ Cann, ${ }^{1}$ the House of Lords held that a mortgagee who had funded the acquisition of a title to land (an 'acquisition creditor') had a right to the land that was superior to that of any other person to whom the purchaser had also granted rights with respect to that title. In Cann itself, this meant that the mortgagee could evict the purchaser's mother, who had been promised that the land would be her home for life and who may have contributed to its acquisition, so giving her an interest under a resulting or constructive trust or a claim in proprietary estoppel. In Scott v Southern Pacific Mortgages, ${ }^{2}$ the principle was applied against vendors who had sold their homes at an undervalue, in the belief that the purchasers would grant them rights that would allow them to remain in occupation for life; the mortgagees who had funded the purchasers' acquisition of title were entitled to evict the vendors on the authority of Cann. These are harsh consequences. ${ }^{3}$ However, they are often said to be justified by some version of an argument from causation: but for the acquisition creditor's agreement to lend, the purchaser would not have been in a position to grant rights over that land to anyone else anyway. There would be no home for the mother to occupy in Cann, if not for the agreement of the mortgagee to lend; the sales in Scott, with the accompanying promises of leases, could not have gone ahead without the agreement of the mortgagees to lend. Thus, the argument goes, ${ }^{4}$ the priority of the mortgagee is justified: a person who has only been able to acquire a property right because of the availability of

\footnotetext{
*Fellow and Tutor in Law at Hertford College, Oxford and Associate Professor of Property Law, University of Oxford. I am grateful to Professor Ben McFarlane, Professor William Swadling, Dr Andreas Televantos, and two anonymous peer reviewers for their valuable comments on previous drafts, and to Mr Felix Kroner for research assistance.

${ }^{1}$ [1991] 1 A.C. 56 ('Cann').

2 [2014] UKSC 52 ('Scott').

${ }^{3}$ Scott,$[95]$.

${ }^{4}$ E.g., PT Evans, 'Abbey National Building Society v Cann' [1991] Conv. 155, 160; P Watts, 'Company Charge' [1990] NZ Recent Law Review 196, 197; S Baughen, 'Some Lessons of Cann' [1991] Conv. 116; M Conaglen, 'Mortgagee Powers Rhetoric' (2006) 69 M.L.R. 583, 595; Mortgage Business plc v O’Shaughnessy [2012] EWCA Civ 17, [55].
} 
mortgage finance should not then be able to assert that very right to the disadvantage of the mortgagee. The conventional interpretation of Cann is that it avoids this normatively problematic result by deeming the purchaser's grant in favour of the mortgagee to take effect at exactly the same moment as the vendor's conveyance of the mortgaged title to the purchaser. Under the 'first in time' rule that normally governs the priority of competing property rights in English law, this conceptual move ensures that the mortgagee will always win in a priority conflict against any other person who claims rights derived from the purchaser.

Unfortunately, both these arguments-the normative argument from causal responsibility and the conceptual argument that the mortgagee is necessarily first in time-are fraught with difficulty. The problem with the normative argument is that, in many situations, it cuts both ways. ${ }^{5}$ In Cann, for example, the purchase of the mortgaged property depended on the mother's consent to the sale of a house previously held on trust for her, the proceeds of sale of which provided part of the purchase price; it is unlikely that the purchase would have gone ahead without it. In Scott, the titles would not have been available for sale at all if the vendors had not been persuaded to sell on the strength of the promised leases. It is not clear why the argument from causation does not work equally well in favour of these parties: but for the mother's consent in Cann and the vendors' agreement to sell in Scott, there would have been no asset to secure the debts owed to the lenders in each case. Other proposed justifications of the principle - such as arguments based on the intentions of the mortgagee in parting with the loan money, ${ }^{6}$ or policy arguments based on the value of recognising purchase-money security interests in English law ${ }^{7}$ - also run into the similar problem that, at least in some situations, identical arguments will be available to the other side. Meanwhile, the idea that a conveyance and a charge can be simultaneous events is conceptually difficult to square with the basic principle that no one can give what she does not have (nemo dat quod non habet): as a matter of logic, the purchaser can only have a power to convey rights over the purchased asset to the lender, or to anyone else, once she has obtained a title to that asset from the vendor. ${ }^{8}$ It is not obvious why, in a case where the purchaser has purported to grant rights to a lender and to

\footnotetext{
${ }^{5} \mathrm{cf}$. R J. Smith, 'More troublesome occupiers' (1990) 106 L.Q.R. 32; 'Mortgagees and trust beneficiaries' (1990) 106 L.Q.R. 545.

${ }^{6}$ E.g., G.D. Goldberg, 'Vivit ac vivat scintilla temporis' (1992) 108 L.Q.R. 380; R Boadle, ‘A purchase money security interest in UK Law?' [2014] LMCLQ 76, 77-78.

${ }^{7}$ E.g., C.J. Davies and H.N. Bennett, 'Fixtures, purchase money security interests and dispositions of interests in land' (1994) 110 L.Q.R. 448; cf. L Gullifer, Goode and Gullifer on Legal Problems of Credit and Security (6 ${ }^{\text {th }}$ edn, London 2017) [5-70] to [5-72].

${ }^{8}$ Church of England Building Society v Piskor [1954] 1 Ch. 553, 561, 564-565.
} 
someone else before the conveyance in her favour, we should say that the grant to the lender takes effect either earlier or later than the other grant. Here, too, the parties seem to be deadlocked.

Intuitively speaking, it may seem fair to respond to this deadlock by giving equal effect to the interests of both parties, to the extent possible. ${ }^{9}$ In practice, this could be done by treating the purchaser as holding the purchased title on trust for a co-contributor and himself in proportion to their contributions, with his own share under the tenancy in common subject to the lender's security interest. Such a solution would avoid the need for a zero-sum contest between the lender and the co-contributor. Disputes about possession or sale would then depend on the lender's ability to obtain an order for sale from a court $;{ }^{10}$ there would be room for an exercise of judicial discretion, balancing the needs and interests of both parties. ${ }^{11}$ Apportionment solutions of this type, however, seems to be ruled out by the normal structure of priority rules in English law. Where two parties have mutually inconsistent property rights in the same asset, the norm is to require one of them to give way to the other; either the first in time prevails, or the other claimant has a defence that allows her to disregard the earlier party's claim. The law does not recognise the possibility of "a 'dead heat' between two mutually inconsistent and competing interests over a legal estate in land", ${ }^{12}$ and proposals to introduce apportionment solutions to priority conflicts in other contexts have not been successful. ${ }^{13}$

This article argues that an apportionment solution to the contest between an acquisition creditor and a financial co-contributor is nevertheless both doctrinally possible and normatively desirable. This is because, contrary to the conventional interpretation of Cann, the principle favouring acquisition creditors does not represent a rule of priority, concerned with the ranking of mutually inconsistent and competing interests. Rather, as the examination of the genesis of the principle in Part II below shows, it reflects a rule of acquisition, concerned with the creation of proprietary rights in equity. The cases treat the lender's financial contribution to a purchase as an independent source of a security interest in the purchased asset, generated by its own intentions regarding the use of the money advanced rather than by any grant on the part of the borrower. As Part III argues, the underlying principle, familiar from elsewhere in the law of trusts, is that rights can arise in response to the authorised substitution of a trust asset without

\footnotetext{
${ }^{9}$ Smith, 'Mortgagees and trust beneficiaries', 549.

${ }^{10}$ Under the Trusts of Land and Appointment of Trustees Act 1996, s. 15.

${ }^{11}$ As in cases like Mortgage Corporation v Shaire [2001] Ch. 743.

${ }^{12}$ Hardy v Fowle [2007] EWHC 2423 (Ch), [103].

${ }^{13}$ A Tettenborn, 'Transfer of Chattels by Non-Owners: Still an Open Problem' [2018] C.L.J. 151, 161.
} 
the need for any fresh grant by an owner of the substitute asset. The equitable interest created by this principle is, however, more limited in its scope than any legal mortgage that may subsequently be granted to the lender by the purchaser; it secures the recovery of the lender's actual financial contribution to acquisition and no more. As such, in a case where there are other financial contributors to acquisition, there is no mutual inconsistency between the rights of the acquisition creditor and the rights of these co-contributors and no need for a zero-sum solution to the dispute between them. In many situations, particularly in the context of registered land, the creditor's acquisition of a registered legal mortgage may put it in a stronger position, giving it a defence that allows it to disregard the interests of the co-contributor and enforce its legal mortgage, securing the full amount of the debt due to it. In the absence of these separate defences, however, an apportionment solution both can and should apply.

\section{GENESIS OF THE PRINCIPLE}

In Cann, the House of Lords approved the decision of the Court of Appeal in Re Connolly Bros (No 2), ${ }^{14}$ identifying that decision as the source of the principle that governed their decision; ${ }^{15}$ no earlier cases were cited. Thus, Re Connolly Bros could be seen as the starting point for any account of the principle. However, this impression is misleading. In fact, the story begins in the mid-nineteenth century with the decision in Meux $v$ Smith. ${ }^{16}$ Meux $v$ Smith and the cases following it are, I argue, essential to making sense of the Court of Appeal's decision in $R e$ Connolly Bros, enabling us to account for features of the reasoning in that case which are otherwise puzzling.

\section{A. The Context of Re Connolly Bros: the Undischarged Bankrupt Case Law}

In Meux v Smith, ${ }^{17}$ one Albin had purchased a leasehold title to a pub, having borrowed part of the purchase price from the brewers who supplied the pub, Meux \& Co. The brewers had lent the money on terms that the debt would be secured by the grant of a legal mortgage. After completion of the conveyance, the vendor deposited the deed directly with them and Albin signed a memorandum promising to grant them a legal mortgage. Unbeknownst to the brewers, however, Albin was an undischarged bankrupt. When they discovered this, they obtained the consent of his assignees in bankruptcy to a sale of the pub to a third party and kept back that

\footnotetext{
${ }^{14}$ [1912] 2 Ch. 25 ('Re Connolly Bros').

15 [1991] 1 A.C. 56, 93, 102.

16 (1843) 59 E.R. 931, cited at first instance in Re Connolly Bros [1912] 2 Ch. 25, 28.

17 (1843) 59 E.R. 931.
} 
part of the sale price that reflected the amount of their loan, plus interest. The assignees in bankruptcy brought an action for money had and received at common law, seeking to recover this amount. Meux \& Co then came to equity, seeking an injunction restraining the common law action and a declaration that they were entitled to "receive and retain [the amount due] out of the proceeds of sale of the premises in preference and priority to the claim of the assignees to such proceeds." 18 They were awarded the injunction they sought, with Shadwell V-C agreeing to continue the injunction-a decision upheld by Lord Cottenham LC on appealand subsequently granting declaratory relief in the terms sought. Meux v Smith was later followed by the Privy Council in Kerakoose v Brooks ${ }^{19}$ and by Farwell J. in Bird v Philpott. ${ }^{20}$

To understand the implication of these decisions, it is important to appreciate the peculiar status of an undischarged bankrupt under the bankruptcy legislation then in force. ${ }^{21}$ Under that legislation, all present and future ${ }^{22}$ assets of an undischarged bankrupt automatically ${ }^{23}$ vested in his assignees or trustees in bankruptcy; a bankrupt became capable of acquiring assets on his own account only when he obtained his certificate of discharge. As Lord Cottenham LC put it in Meux $v$ Smith, the result was that an undischarged bankrupt "had no right and no power, as against [his assignees in bankruptcy], to create any interest in the property which was in himself"; ${ }^{24}$ as soon as he purported to acquire any asset, it vested by statute in his assignees who alone had the power to deal with it. As against a lender who had bargained with the undischarged bankrupt for security over an after-acquired asset, therefore, the assignees or trustees in bankruptcy had a potent argument from the nemo dat principle: the undischarged bankrupt simply had nothing to give, by statute. ${ }^{25}$

Despite the apparently impeccable logic of this argument, the courts did not accept it. In Meux $v$ Smith, having set out the nemo dat argument, Lord Cottenham LC went on to say that the lenders could avoid it by denying that they were seeking to maintain "any title derived from the uncertificated bankrupt". ${ }^{26}$ Instead, he said, they could derive their lien from the terms of their agreement with him: they would succeed if they could show that "previously to the

\footnotetext{
18 (1843) 59 E.R. 931, 936.

19 (1860) 15 E.R. 376.

${ }^{20}$ [1900] 1 Ch. 822.

${ }^{21}$ Bankrupts (England) Act 1825 (6 Geo 4 c 16), at issue in Meux v Smith; Indian Insolvency Act 1848 (11 \& 12 Vict c 21), at issue in Kerakoose v Brooks; Bankruptcy Act 1883 (46 \& 47 Vict c 52), at issue in Bird v Philpott.

22 Bankrupts (England) Act 1825, s 64; Indian Insolvency Act 1848, s 7; Bankruptcy Act 1883, s 44.

${ }^{23}$ Contrast the modern position under the Insolvency Act 1986, s. 307.

${ }^{24}$ (1843) 59 E.R. 931, 938.

${ }^{25}$ Compare Bird v Philpott [1900] 1 Ch. 822, 825-826.

26 (1843) 59 E.R. 931, 938.
} 
contract being carried into effect between [the vendor] and the bankrupt, there was a contemporaneous contract between [the bankrupt] and [the lenders], by which it was agreed that, although [the bankrupt] was to take a lease in his own name, yet that the lease so taken in his own name was to the extent of the money advanced to be for the benefit of [the lenders]."27 If they could prove the existence of such an agreement, as they eventually did to the satisfaction of Shadwell V-C, their equitable lien would have arisen simultaneously with the vesting of title in the bankrupt, under a single transaction, ${ }^{28}$ and so would bind his assignees in bankruptcy.

There is an obvious tension in Lord Cottenham's reasoning on this point. On the one hand, we are told that the lenders' title was not derived from Albin and so they could not be affected by the limits on his powers of grant under the bankruptcy legislation. On the other hand, we are told that the existence of that lien depended on the terms of their bargain with Albin himself. If the lenders' lien depends on their agreement with the bankrupt, how can it also be true that their title does not derive from the bankrupt?

One possible way of resolving this apparent contradiction is to focus on the possibility of a separate bargain between the lender and the vendor, ${ }^{29}$ rather than the lender and the purchaser. If the vendor had agreed that the lender was to have a lien securing the debt owed by the purchaser, it would make some sense to say that this lien arose at the same moment as title vested in the purchaser and did not depend on any grant by the purchaser; the vendor certainly had the power to make such grants and could perhaps, in theory, have done so under the same transaction by which he conveyed the leasehold title to the purchaser. ${ }^{30}$ On the facts of Meux $v$ Smith itself, this solution has some surface plausibility. As was apparently the usual practice when a lease of a pub was to be sold to a purchaser who could not buy it for ready money, the vendor appears to have taken the lead in managing Albin's negotiations with the brewers. All three parties were present at a crucial meeting at the pub, during which the lenders' agent gave a cheque, representing the amount of the purchase-money advanced, directly to the vendor; this cheque was never cashed but instead set off against the existing debts owed by the vendor to the lenders. However, a vendor-focused explanation of the outcome in the case does not fit easily with Lord Cottenham's own account of the source of the lender's rights: he scrupulously distinguishes the separate contracts between the vendor and the purchaser and the

\footnotetext{
27 ibid.

${ }^{28}$ (1843) 59 E.R. 931, 940.

${ }^{29} \mathrm{cf}$. WR Fisher, The law of mortgages and other securities upon property ( $2^{\text {nd }}$ edn, London 1868) 857. I am grateful to Dr Andreas Televantos for drawing my attention to this source.

${ }^{30}$ Although see Re Bond Worth [1980] Ch. 228, 253-256.
} 
lenders and the purchaser, and he makes it plain that the lenders' rights arose in response to their agreement with the purchaser specifically. Nor is a vendor-focused explanation available in later cases, such as Bird v Philpott and Re Connolly Bros, where there was a more conventional distance between the lender and the vendor and the only connection between them was the vendor's receipt of funds ultimately derived from the lender.

Another possible interpretation of the principle is that it represents the application of an exception to the nemo dat principle, in favour of a subset of bona fide purchasers for value who lack notice of the bankruptcy. ${ }^{31}$ The brewers in Meux $v$ Smith were in fact unaware of Albin's past bankruptcy when they advanced the money, and invoked their lack of notice as part of their argument for equitable relief. ${ }^{32}$ However, this focus on notice does not align with Lord Cottenham LC's reasoning, which makes no reference to the lenders' ignorance of Albin's bankruptcy. This conclusion is reinforced by the Privy Council decision in Kerakoose $v$ Brooks. ${ }^{33}$ In that case, an undischarged bankrupt had borrowed Rs 10,000 from the claimant for the purpose of purchasing certain chattels for use in his business; on the same day that he acquired the chattels, he mortgaged them in favour of the claimant as security for the loan. At first instance, in the Supreme Court of Judicature at Madras, Sir Adam Bittleston distinguished Meux v Smith on the basis that the claimants there had not known of the bankruptcy, whereas here "the defendant knew that he was dealing with an insolvent" and must, therefore, be "be taken to have consented to advance the money upon such security as the insolvent was legally competent to give." 34 The Privy Council allowed an appeal against the decision, holding that the only issue in the case was whether the appellant had advanced money for the purpose of buying property "subject to an agreement, that it is to be laid out in that particular manner, and that the property is to be assigned to the person who advances the money in order to secure the repayment." 35 If so, the purchase of the chattels and the grant of the chattel mortgage represented "one transaction by which the Insolvent never acquired anything except subject to the lien of the creditor, and the Assignee can stand in no better position. ${ }^{36}$ Notice was

\footnotetext{
${ }^{31}$ Compare Cohen v Mitchell (1890) 25 Q.B.D. 262, distinguished in Re New Land Development Association and Gray [1892] 2 Ch. 138.

32 (1843) 59 E.R. 931, 935. Meux v Smith was interpreted in these terms by E Sugden, A concise and practical treatise of the law of vendors and purchasers of estates $\left(14^{\text {th }}\right.$ edn, London 1862) 541. I am grateful to Dr

Andreas Televantos for drawing my attention to this source.

33 (1860) 19 E.R. 559, 566.

${ }^{34}$ (1860) 19 E.R. 559, 563.

35 (1860) 19 E.R. 559, 566.

${ }^{36}$ ibid.
} 
irrelevant.

The clue to the puzzle seems to lie in Lord Cottenham's characterisation of the terms of the bargain between the purchaser and the lender. He does not characterise it simply as an agreement that the purchaser would grant security over the purchased asset to the lenders, in consideration for the money lent to him. Such a promise could not have been performed, under the bankruptcy legislation. Rather, it is an agreement by the purchaser that the lease, although "taken in his own name", will "to the extent of the money advanced" be for the benefit of the lender. In other words, the focus is not on conditions attached to the sale of the land by the vendor (who may not be a party to the transaction) or the purchaser (who is under a disability), but rather on conditions attached to the advance of the purchase money by the lender.

Bird $v$ Philpott ${ }^{37}$ clearly illustrates the distinction between giving effect to the purported grant of the purchaser and giving effect to the intentions of the lender so far as they relate to the money advanced. In that case, the undischarged bankrupt, one Templeman, was in the general habit of borrowing money from his solicitor, Bird. In May 1898, Templeman contracted to buy titles to three plots of building land at an auction; he borrowed first the initial deposit and then the rest of the purchase price ( $£ 110,3 \mathrm{~s}, 3 \mathrm{~d}$ in total) from Bird. A month later, several weeks before the purchased title was conveyed to him, he executed a deed purporting to grant Bird a mortgage over that title, as well as over certain other estates held by him at the time. Under the terms of the deed, this mortgage secured repayment of all the debts he owed Bird, including any future advances; by the date of the litigation, with the accumulation of interest, this came to over $£ 700$. In the subsequent litigation between Templeman's original ${ }^{38}$ trustee in bankruptcy and Bird, Farwell J. limited Bird's claims to the land that had been purchased using the money he had advanced and limited his recovery to the amount advanced. He found as a fact that the "property was acquired by Mr Bird's money entirely .... under an agreement ... that he was making the advance with the intention of taking the benefit of the conveyance when it was obtained, to the extent of his charge". ${ }^{39}$ The result, on the authority of Meux v Smith, was that Mr Bird was entitled "to the extent of the money which he has paid to a charge on these last three plots". ${ }^{40}$ Although the mortgage purportedly granted to him by Templeman secured repayment of all the debts he owed to Bird, the amount secured by the

\footnotetext{
37 [1900] 1 Ch. 822.

38 The fact of Templeman's first bankruptcy came to light when he was bankrupted again; the second trustee in bankruptcy was also party to the litigation.

${ }^{39}$ [1900] 1 Ch. 822, 830.

${ }^{40}$ [1900] 1 Ch. 822, 831.
} 
charge that bound the first trustee in bankruptcy was $£ 110,3 \mathrm{~s}$, and $3 \mathrm{~d}$ - the amount advanced, without interest. ${ }^{41}$ Thus, in Bird v Philpott, the lender's intentions in relation to the money advanced came apart from the terms of his contract with the purchaser and the court gave effect to the former and not to the latter.

\section{B. The Decision in Re Connolly Bros: the Irrelevance of Questions of Priority}

In Re Connolly Bros, ${ }^{42}$ a company had granted charges over all its present and future property to debenture-holders, on terms that expressly forbade the creation of "any mortgage or charge ... in priority to or ranking pari passu" ${ }^{43}$ with the debenture-holders' charges. The debentures were registered under the Companies Act 1900, then in force. Three years after the grant of the charges, the company borrowed $£ 1000$ from one Mrs O’Reilly for the purpose of buying a title to land in Manchester, agreeing to grant her a charge over the property to secure repayment of the debt. Mrs O'Reilly's solicitor, who also acted for the vendor and the purchaser, did not make any search of the company charges register at the time of the transaction. ${ }^{44}$

Some years later, when one of the debenture-holders applied for an account, the Master in Chancery certified that Mrs O’Reilly’s charge, securing repayment of $£ 800$ still due to her, took priority over the debenture-holders' charge. The debenture-holders brought an action seeking to vary the certificate. At first instance, Warrington J. refused to do so, on the authority of Meux v Smith. His key finding of fact was that Mrs O'Reilly "did not agree to advance this money unconditionally; but that she agreed to make this advance for the purpose and sole purpose of paying off this purchase-money, and under a contemporaneous agreement that she was to have a charge upon the property so purchased." ${ }^{45}$ On this basis, he held, the case came within the authority of Meux $v$ Smith, which he explained in two ways. On the one hand, Warrington J. suggested that Mrs O'Reilly's payment of the purchase price to the vendor meant that she was subrogated to the debt owed to the vendor, giving her the benefit - and the priority —of the unpaid vendor's lien, ${ }^{46}$ despite the lack of any "direct agreement" between her and the vendor that she was to be so subrogated. Alternatively, he said, the case could also be put in terms of what the company had acquired when it bought the title: as against Mrs O'Reilly, it had never acquired any title "except subject to the obligation of giving her a charge

\footnotetext{
${ }^{41}$ [1900] 1 Ch. 822, 832.

42 [1912] 2 Ch. 25.

43 [1912] 2 Ch. 25.

44 [1912] Ch. 25, 27-28.

45 [1912] 2 Ch. 25, 28.

46 ibid.
} 
for the amount of the purchase-money which she ... advanced"; ${ }^{47}$ that is, it had only ever acquired "the equity of redemption, subject to the security created in favour of Mrs O'Reilly." 48 Acknowledging that these may be simply be different ways of putting the same point, ${ }^{49}$ he held that both analyses led to the conclusion that Mrs O'Reilly's equitable charge took "priority over the interest of the company itself", ${ }^{50}$ and thus took priority over the company's grantees, the floating chargees. The reason for her priority, as the analogy to subrogation to the unpaid vendor's lien suggests, was the fact of having advanced the funds of the purchase to the vendor; the effect was to give her a charge "for the amount of purchase-money she so advanced." 51

The decision was upheld by the Court of Appeal. Echoing Warrington J.'s second formulation of the principle, Cozens-Hardy MR said that "in equity", the company had never acquired an "unincumbered fee simple", but only "the equity of redemption...subject to Mrs O'Reilly's charge[.]"52 In the Court of Appeal, however, the explanation for this outcome was put in the language of contract, with a focus on the "real transaction" 53 or "bargain" between the company and Mrs O'Reilly. Cozens-Hardy MR put the question in terms of whether the company "as between themselves and Mrs O'Reilly" had become "the absolute owners of the property". ${ }^{54}$ In answering this question in the negative, he was attentive to the fact that Mrs O'Reilly had effectively paid the vendor, carefully charting the path of the funds from her cheque to the purchaser's bank account to the cash paid to the vendor. However, the focus of his analysis is on the bargain or contract as the source of Mrs O'Reilly's rights: the fact that she paid the vendor is treated as evidence of that bargain. Similarly, Buckley LJ. held that the issue turned on whether, "neglect[ing] the debenture-holders altogether", Mrs O'Reilly had "a contractual right as between herself and the company to have the security". 55

Read in isolation, these brief judgments of the Court of Appeal are puzzling: their focus on the position "as between Mrs O'Reilly and the company" seems to evade the very question before the court. After all, the litigation in the case was not between Mrs O'Reilly and the company but between Mrs O'Reilly and the debenture-holders. Cozen-Hardy MR's focus on the position "in equity" might provide some explanation for the third-party effect of Mrs

\footnotetext{
${ }^{47}$ [1912] 2 Ch. 25, 29.

48 ibid.

${ }^{49}$ Ibid.

50 ibid.

51 ibid.

52 [1912] 2 Ch. 25, 31.

53 ibid.

54 ibid.

55 ibid.
} 
O'Reilly's contractual rights: we are familiar with the principle that, in some contexts, an obligation that governs the exercise of a specific right can bind later disponees of that very right. ${ }^{56}$ However, it is not clear how this argument helps Mrs O'Reilly against the debentureholders because it is not clear why they qualify as later disponees of the right in question. Under the terms of the debentures, the company had contracted to grant them a first-ranking charge over any asset that they acquired in the future, and this contract was made three years before the contract with Mrs O'Reilly. As established in Holroyd v Marshall, ${ }^{57}$ contracts of this kind take immediate effect in equity as soon as the relevant asset vests in the promisor. Thus, if Re Connolly Bros concerns a contest between two contractual promises that are capable of taking proprietary effect in equity, as Buckley LJ's framing might seem to suggest, it is not clear why the later promisee should win over the earlier promisee.

This problem becomes even more pressing when we consider the court's handling of the question of notice. In the Court of Appeal, that question formed the heart of the argument made by counsel for the debenture-holders. They argued that Mrs O'Reilly had constructive notice of the debenture-holder's charge because her agent had failed to investigate the company charges register and she "must take the consequences of not having done so." ${ }^{\circ 8}$ However, the judges simply did not engage with the notice point in their substantive judgments. Rather, the point was laconically dismissed in the course of argument on the basis that "the point of notice does not arise if the court is against you on the question as to what the company actually acquired." ${ }^{59}$ Under the standard logic of priority conflicts in equity, the reasoning of the Court of Appeal in Re Connolly Bros thus seems profoundly opaque: both the first in time rule and the rule favouring a bona fide purchaser without notice are disregarded without explanation.

However, when the case is read in the light of the authorities relied upon by Warrington J. at first instance, these difficulties can be resolved. If, as in Meux v Smith, Mrs O'Reilly's proprietary rights arose in response to her own intentions in paying for the acquisition of the land in the company's name, she was not in the same position as the chargees: unlike them, her security did not depend on the company's specifically enforceable contractual duty to grant her such security, but on her title to her own money. Her claims to assets purchased using that

\footnotetext{
${ }^{56}$ B McFarlane and R Stevens, 'What's Special About Equity?' in D Klimchuk, I Samet, and HE Smith (eds), Philosophical Foundations of the Law of Equity (Oxford 2020) 191, at 203-206. Examples include Lysaght v Edwards (1876) 2 Ch. D 499, Pullan v Koe [1913] 1 Ch. 9, and Holroyd v Marshall (1862) 10 HL Cas 191, 11 E.R. 999; compare FHR European Ventures LLP v Cedar Capital Partners LLC [2014] UKSC 45, [33]. 57 (1861-2) 10 HLC 191.

58 [1912] 2 Ch. 25, 30.

59 ibid.
} 
money, therefore, could not be affected by notice of the company's past promises concerning its present or future assets. Warrington J's invocation of the notion of subrogation to the unpaid vendor's lien makes the same point: the source of her rights is not (only) her act of contracting with the company, but rather her act of paying the purchase-money to the vendor, on the basis of the conditions expressed in that contract.

\section{The Principle in Re Connolly Bros: Contribution to Acquisition as a Source of Rights}

Three key points emerge from Re Connolly Bros, read in the light of the earlier authorities. First, the acquisition creditor gains her security interest by some mechanism that is independent of any power of the purchaser to grant such rights: it is for this reason that fetters on the purchaser's power of grant, whether under the terms of a prior agreement with a third party or under the bankruptcy legislation, do not operate to defeat the creation of the security. Since the nemo dat principle is not engaged in these situations, factors that are usually relevant to the application of an exception to that principle - such as the existence of constructive ${ }^{60}$ or even actual $^{61}$ notice of the purchaser's prior obligations - are disregarded. Even if the lender knows or ought to know that the purchaser is not supposed to be granting rights of this kind over his own assets to her, this knowledge does not affect her assertion of rights over assets that have been acquired using money advanced by her.

Secondly, and somewhat paradoxically, the courts emphasise the importance of the agreement between the creditor and the purchaser as the source of the creditor's rights. It is this bargain or transaction that explains why the lender's security takes priority over the purchaser's own interest to the purchased asset, and thus over the interests of any subsequent right-holder, including a trustee or assignee in bankruptcy. Despite appearances, this emphasis on the terms of the lender's agreement with the purchaser does not contradict the premise that her interest in the purchased asset arises independently of any decision or exercise of power by the purchaser. This is because the terms of the agreement matter as evidence of the conditions attached by the lender to the advance of the loan money, not as evidence of the terms of the purchaser's obligation to make a future grant over the purchased asset. This is demonstrated by the fact that, as Bird $v$ Philpott shows, the court gives effect to the bargain only in so far as it relates to the purchase-money advanced by the lender for the purpose of buying the asset: where the purchaser has promised to secure further debts owed to the lender, the principle does

\footnotetext{
${ }^{60}$ As in Re Connolly Bros.

${ }^{61}$ As in Kerakoose v Brooks.
} 
not justify the enforcement of that obligation to the disadvantage of other right-holders.

Finally, the courts phrase their conclusion that the acquisition creditor's security does not depend on any grant of the purchaser in terms that are familiar to us from the subsequent case law. For example, they sometimes use temporal language, saying that the lender's security interest arises simultaneously with the vesting of the purchased estate in the purchaser ${ }^{62}$ oras a negative correlative of the same proposition - that there is no moment in time when that estate vests in the purchaser free from the lender's security. ${ }^{63}$ In other places, they say that the transfer of the purchased estate and the creation of the lender's security take place under a single transaction. ${ }^{64}$ However, there is no evidence that these conclusions depend on any facts about the closeness in time of the transactions of sale and charge. In Bird v Philpott, for example, there was a gap of several weeks between Templeman's execution of the deed mortgaging the land to Bird and the completion of the conveyance in his favour. There was no suggestion that the gap between these two events prevented the 'single transaction' analysis from operating; it was sufficient that the timing of the two transactions evidenced Bird's intention, in advancing the money, that its repayment should be secured by an interest in the purchased land. ${ }^{65}$ Nor is there any evidence that the principle depends on the interpretation of the conveyance between vendor and purchaser as being a single tripartite transaction, with the vendor intentionally reserving a security interest in favour of the lender. For example, in $R e$ Connolly Bros, the absence of any "direct agreement" between the vendor and Mrs O'Reilly was no obstacle to the principle operating in her favour. It appears, therefore, that language of the 'single transaction' is used in these cases to express a conclusion of law that flows from the fact of the purchase of land with money advanced by the lender. That conclusion does not depend on any further facts to do with the timing of transactions, or the identification of the parties to the conveyance or charge and the construction of their intentions.

\section{THE PRINCIPLE IN THE MODERN LAW}

Thus, the Re Connolly Bros line of authority treats a lender's decision to pay for the purchaser's acquisition of an asset, on condition of a grant of security, as a source of a proprietary interest in the purchased asset. This section considers the extent to which that principle represents the modern law, arguing that it has a stronger principled basis and makes better sense of the modern

\footnotetext{
${ }^{62}$ As in Meux $v$ Smith.

${ }^{63}$ As in Re Connolly Bros.

${ }^{64}$ As in Meux $v$ Smith and Kerakoose v Brooks.

65 [1900] 1 Ch. 822, 831.
} 
cases than the rival account, which treats the purchaser's grant in favour of the lender as taking effect earlier in time than any other grant.

\section{A. Justifying the Priority of the Acquisition Creditor: the Nemo Dat Problem}

One of the problematic features of the Re Connolly Bros line of authority, as has been noted, is its apparent disregard for the nemo dat principle. The nemo dat principle reflects a fundamental intuition ${ }^{66}$ associated with our concept of property: this is the idea that a property right, once it has arisen, can normally only be lost or limited by the consent of the right-holder. It is this principle that explains why, in standard priority disputes, it is the first in time that prevails by default. For example, suppose a freeholder, A, first grants a lease to B and then grants a mortgage to C. From the moment of its creation, B's lease imposes a duty of noninterference on all subjects of the legal system, including both $\mathrm{A}$ and $\mathrm{C} .{ }^{67}$ If $\mathrm{C}$ wishes to take possession of the land in a manner inconsistent with the terms of B's lease, it needs to show how it has been released from its pre-existing duty to B. It cannot point to A's grant in its favour as, in itself, ${ }^{68}$ representing a reason why it should be so released; only B, not A, can have the power to release $\mathrm{C}$ from a duty owed to B. By contrast, when B obtained her lease from A, C's mortgage did not yet exist and neither A nor B owed any duties to C. B is thus entitled to use the land inconsistently with the terms of the mortgage, unless $\mathrm{C}$ can show that some fresh event has occurred to impose a duty not to do so upon her.

While the position in equity is more complex than this, ${ }^{69}$ in that most $^{70}$ equitable interests do not impose immediate duties of non-interference on all strangers, the first in time rule that applies in equity is commonly thought to have an analogous rationale. ${ }^{71}$ If A declares a trust of his title to land in favour of $\mathrm{B}$ and then mortgages that title to $\mathrm{C}$ in breach of trust, $\mathrm{C}$ may ${ }^{72}$ come under a duty not to use its rights under the mortgage inconsistently with the terms

\footnotetext{
${ }^{66}$ AM Honoré, 'Ownership' in AG Guest (ed), Oxford Essays in Jurisprudence: First Series (Oxford 1962) 107, 119; the link to the nemo dat principle is discussed by A Tettenborn, 'Transfer of Chattels by Non-Owners: Still an Open Problem' [2018] C.L.J. 151, 159.

${ }^{67}$ Street $v$ Mountford [1985] A.C. 809, 816.

${ }^{68}$ Such a grant may, however, form an element of a defence based on purchase for value, e.g., under the Land Registration Act 2002, s. 29(1). In such a case, it is C's reliance on the register, rather than A's consent, that provides the reason for its release from the duty owed to B.

${ }^{69}$ S Douglas and B McFarlane, 'Defining Property Rights' in J Penner and H Smith, Philosophical Foundations of the Law of Property (Oxford 2013) 219, at 240-243.

${ }^{70}$ Restrictive covenants are an exception: Re Nisbet and Pott's Contract [1905] 1 Ch. 391.

${ }^{71}$ W Swadling, 'Restitution and Bona Fide Purchase' in Swadling (ed), The Limits of Restitutionary Claims: A Comparative Analysis (London 1997) 78, at 81-82.

${ }^{72}$ The duty may arise only if $\mathrm{C}$ acquires knowledge of the breach of duty while still holding a proprietary interest in the asset: S Agnew and B McFarlane, 'The Paradox of the Equitable Proprietary Claim' in S Agnew and B McFarlane (eds), Modern Studies in Property Law: Volume 10 (Oxford 2019) 303.
} 
of the trust $7^{73}$ it can escape this liability, while it still holds the mortgage, only if it can show that the beneficiary consented to that mortgage ${ }^{74}$ or that some other event has supervened to release it from its liability to $\mathrm{B} .{ }^{75}$ This structural feature of the law, which requires a subsequent grantee, $\mathrm{C}$, to explain why it should not be bound by a duty or a liability to an earlier grantee, $\mathrm{B}$, rather than vice versa, ${ }^{76}$ is shared by both legal and equitable interests in land and is justified by the law's broad normative commitment to preserving vested rights from being lost without the consent of the right-holder.

However, as we have seen, the law on the position of acquisition creditors seems to defy this logic. In the old cases involving undischarged bankrupts, legal title to assets acquired by the bankrupt (A) automatically vested, by statute, in his assignees or trustees in bankruptcy (B); thus, as soon as he purported to acquire a title to land, other subjects of the legal system would have come under an immediate duty of non-interference with that land, owed not to him but to his trustees in bankruptcy. Any subsequent grant of security to a creditor (C) ought to be ineffective to release $\mathrm{C}$ from that duty owed to $\mathrm{B}$ in the absence of a special defence. $R e$ Connolly Bros poses a parallel problem in equity. The company (A) was under a duty to the debenture-holders (B) not to grant ranking security interests to third parties; as soon as it acquired its title to the purchased land, this duty attached to its exercise of the rights comprised in that title. Any subsequent grant of security to Mrs O'Reilly (C) would have represented a breach of that duty; her discovery of the fact of this breach, while she still held her security interest in the land, should then have affected her conscience in the absence of the equity's darling defence - a defence which was doubly unavailable to her, as a purchaser for value of a merely equitable charge ${ }^{77}$ and as a purchaser with constructive notice of the debenture-holders' charge and its terms. Thus, if the acquisition creditor is characterised as a subsequent grantee of the purchaser, the nemo dat principle dictates that the creditor ought to lose to the trustee in bankruptcy or the prior debenture-holder in the absence of a special defence; any other result would seem to involve the trustees in bankruptcy or the debenture-holders losing their existing property rights, without their consent, for reasons that are unclear.

In response to this problem, courts have come up with two different ways to avoid characterising the acquisition creditor as a subsequent grantee of the purchaser: one denying

\footnotetext{
73 As in Williams \& Glyn's Bank v Boland [1981] A.C. 487.

${ }^{74}$ Ali v Dinc [2020] EWHC 3055, [318].

${ }^{75}$ E.g., a registered disposition for value of a registered estate: Land Registration Act 2002, s 29(1).

${ }^{76}$ Pilcher v Rawlins (1871-72) L.R. 7 Ch. App. 259, 261.

${ }^{77}$ Phillips $v$ Phillips (1861) 45 E.R. 1164.
} 
that the creditor is a grantee of the purchaser, and the other denying that the grant in favour of the creditor is subsequent to any other grant in favour of a third party. In the older cases, as we have seen, judges adopted the first approach, treating the creditor's right as arising in response to some event other than an express grant and, therefore, as unaffected by limits on the purchaser's powers of grant. In the twentieth century, a different analysis has become conventional; in this view, the acquisition creditor does obtain its security in response to a grant by the purchaser, but this grant takes effect at precisely the same moment in time as the vendor's conveyance of the mortgaged estate to the purchaser and, thus, takes place earlier in time than any other grant by the purchaser to a third party.

This view of the law made its first appearance in Coventry Permanent Building Society $v$ Jones, ${ }^{78}$ where Harman $\mathrm{J}$ framed the dispute between an acquisition creditor and a tenant of the purchaser as depending, in part, on whether there was a "scintilla temporis" moment of time between the vendor's conveyance to the purchaser and the purchaser's grant of a legal charge to the creditor, within which a tenancy by estoppel could arise. Jones differs from earlier authorities ${ }^{80}$ in treating the chronological order of transactions as genuinely consequential to the priority of the creditor. The weight placed by Harman $J$ on the actual chronological sequence of events is reflected by the fact that he did not treat the rejection of the "scintilla temporis" as decisive to solving the dispute between the tenants and the creditor. Instead, he went on to consider the possibility that the tenants could have obtained an equitable right from the purchaser, carved out of her interest under a contract for sale, ${ }^{81}$ before the conveyance and thus before the charge in favour of the acquisition creditor. His conclusion, that this equitable tenancy did not bind the mortgagee because it was not on the land charges register, ${ }^{82}$ suggests that such an interest could in principle have arisen in favour of the tenant and bound the creditor as being earlier in time. ${ }^{83}$

These two analyses justify the apparent displacement of the nemo dat principle in fundamentally different ways. If the acquisition creditor acquires its rights from the purchaser, but that grant is deemed to take place at the same moment in time as the vendor's grant in

\footnotetext{
78 [1951] 1 All E.R. 901.

79 [1951] 1 All E.R. 901, 903.

${ }^{80}$ None of the earlier cases are cited in Jones, which was associated with the Re Connolly Bros only later: Mornington Permanent Building Society v Kenway [1953] Ch. 382, 385.

${ }^{81}$ [1951] 1 All E.R. 901, 903.

82 [1951] 1 All E.R. 901, 904.

${ }^{83}$ For example, if the land had been registered and the tenants in actual occupation: Woolwich Equitable Building Society v Marshall [1952] Ch 1, 9.
} 
favour of the purchaser, the nemo dat principle does seem on its face to be engaged. Under the normal premises of English property law, the transfer of title from the vendor to the purchaser is a logical prerequisite for the purchaser to be able to grant rights to the acquisition creditor or to anyone else; ${ }^{84}$ it is not clear what it means to say that these two transactions are simultaneous in the eye of the law, in the absence of genuine participation ${ }^{85}$ by the vendor in the act of charging the estate to the mortgagee. This account of the law does, therefore, disregard the logic of the nemo principle in favour of an acquisition creditor; the question is why this should be so. In Cann, Lord Oliver proposes a number of reasons why the "attractive legal logic" 86 of the nemo dat principle should be disregarded in favour of the lender: these include the causal dependency of the purchaser on the funds supplied by the lender, the fact that the lender will normally advance funds to the purchaser only on condition that it be granted a charge, and the closeness in time of the conveyance and the charge, with the purchaser normally executing the charge on the same day as, or earlier than, the conveyance. Of these factors, as Smith notes, causal responsibility for acquisition and financial contribution need not be the sole province of the lender. Meanwhile, it is difficult to explain why the purchaser's decision to execute the charge before or after the conveyance, or on the same day, is relevant, given that the usual justification for the first in time rule, the nemo dat principle, cannot operate in this situation. As Smith argues, this interpretation of the law "comes perilously close to a simple assertion that a mortgagee wins because he is a mortgagee", ${ }^{87}$ laying the legal system open to the criticism that the judges simply prefer institutional lenders over other parties, regardless of principle. ${ }^{88}$

By contrast, if the acquisition creditor's right arises in response to some event other than a grant by the purchaser, the nemo dat principle is simply irrelevant; that principle only has salience in situations where the two competing parties derive mutually inconsistent rights in the contested asset from the same source. ${ }^{89}$ In the examples above, it is because both B and $\mathrm{C}$ derive their title from A that previous limits on A's powers of grant in favour of B will affect C. In a situation where $\mathrm{C}$ instead obtains a right by a different mode of acquisition, this argument is unavailable to B. For example, suppose that B lends his chattels to A who attaches

\footnotetext{
${ }^{84}$ Church of England Building Society v Piskor [1954] 1 Ch. 553, 561, 564-565.

${ }^{85}$ Such a characterisation of a transaction will normally depend on the intentions of the parties: T Cutts, 'Tracing, Value, and Transactions' (2016) 79 M.L.R. 381, 398-399, and authorities discussed there.

${ }^{86}$ [1991] A.C. 56, 92.

${ }^{87}$ Smith, 'Mortgagees and trust beneficiaries' 548.

88 cf. Conaglen, 'Mortgagee Powers Rhetoric'.

${ }^{89}$ E Durfee, 'Priorities' (1959) 57 Michigan Law Review 459, 469-471.
} 
them to C's land in such a way that they become part and parcel of the land..$^{90}$ The effect of the annexation will be to extinguish B's title to his chattels, which will now belong to C as part of the land $;{ }^{91}$ there is no room for a nemo dat argument that A had no power to dispose of B's title to his chattels in this way, ${ }^{92}$ and it is irrelevant that B's title to the chattels arose earlier in time than the act of annexation that turned them into part of C's land. Such a result is consistent with the law's basic commitment to the principle that persons are not to be deprived of their vested rights without their consent, because it follows from the initial content of the rights originally held by the parties. It is an inherent limit on a title to a chattel that it is lost when the chattel itself ceases to exist ${ }^{93}$ conversely, it is an inherent feature of a title to land that it includes an entitlement to accretions. In such cases, it is for the law to specify the precise content of a right acquired by these means, including by balancing the interests of affected parties in situations where these interests conflict. ${ }^{94} \mathrm{~A}$ model focused on contribution as a source of the acquisition creditor's interest thus leaves open the possibility that the relevant security interest should have a narrower scope than the mortgage promised to the lender by the purchaser, as Bird $v$ Philpott suggests, leaving open the possibility that a third party contributor's interests might be taken into account while still paying due regard to the interests of the creditor.

Two problems remain. First, it is necessary to identify the event that gives rise to the acquisition creditor's interest in the land, and to explain why, despite the creditor's reliance on a contractual bargain with the purchaser, that event does not represent a derivative mode of acquisition of rights. Secondly, it is necessary to consider whether such an analysis can be reconciled, at the level of authority, with the outcomes in the leading cases-especially Cann itself. The remaining sections of this part tackle both problems, arguing that the lender obtains an equitable interest in the purchased asset in response to an authorised substitution of rights held on trust and that the outcomes in the modern cases are consistent with this analysis.

\section{B. Contribution as an Original Mode of Acquisition: Substitution and the Conditional Loan}

As has been noted, judges frequently explain the priority of the acquisition creditor by reference to its intentions in parting with the loan money, and the use subsequently made of

\footnotetext{
${ }^{90}$ Elitestone v Morris [1997] 1 W.L.R. 687, 691.

${ }^{91}$ Reynolds $v$ Ashby \& Son [1904] A.C. 466.

92 As noted by S Bridge, E Cooke, and M Dixon, Megarry \& Wade: The Law of Real Property (9 $9^{\text {th }}$ edn, London 2019) [22-023].

93 JS Rogers, 'Negotiability, Property, and Identity’ (1991) 12 Cardozo Law Review 471, 490.

${ }^{94}$ See, for example, Jones $v$ De Marchant (1918) 28 D.L.R. 561.
} 
that money. Often, they put their conclusion in terms of defining the real meaning of the conveyance, holding that although title is nominally or apparently taken in the name in the purchaser, the conveyance is really ${ }^{95}$ taken for the benefit of the creditor, at least to the extent of its charge. The latter explanation is sometimes put in the form that, on a true or 'realistic' understanding of the transaction, the purchaser acquires nothing by the conveyance but an equity of redemption, ${ }^{96}$ subject to the charge of the acquisition creditor. In justifying this conclusion, courts also sometimes chart the precise series of transactions leading up to the purchase of the land, emphasising the fact that the direct payee of the vendor is normally the creditor, or a solicitor acting for the creditor, rather than the purchaser. ${ }^{97}$

Both these features of the judicial reasoning - the focus on the source of funds used to acquire an asset, and the distinction between an apparent conveyance in the name of a given person and the real or true transaction, which is that the purchaser takes for the benefit of some other-can also be found in the case law governing purchase-money resulting trusts. ${ }^{98}$ As Mee has pointed out, ${ }^{99}$ it is a peculiar feature of these cases that, where $\mathrm{X}$ funds a purchase in the name of Y, the courts treat evidence of X's unilateral intentions as decisive in settling whether the presumption of resulting trust is rebutted or not-even where $\mathrm{X}$ is not a party to the transaction of sale between $\mathrm{Y}$ and the vendor of the assets, ${ }^{100}$ and even where $\mathrm{Y}$ and the vendor appear on the face of the conveyance to have different intentions. ${ }^{101}$ In the case of the purchasemoney resulting trust, this can be explained on the basis that Y's purchase of the asset represents a substitution ${ }^{102}$ of an asset held on trust for X. If, when $\mathrm{X}$ paid the money to $\mathrm{Y}$, he

\footnotetext{
${ }^{95}$ E.g., Meux v Smith (1843) 59 E.R. 931, 938; Bird v Philpott [1900] 1 Ch. 822, 830.

${ }^{96}$ E.g., Re Connolly Bros [1912] 2 Ch. 25, 31; Security Trust Co v Royal Bank of Canada [1976] A.C. 503, 521; Abbey National Building Society v Cann [1991] A.C. 56, 92, 102; Whale v Viasystems Ltd [2002] E.W.C.A. Civ 480, [29], [73]; Scott v Southern Pacific Mortgages [2014] UKSC 52, [115].

${ }^{97}$ E.g., Re Connolly Bros [1912] 2 Ch. 25, 31; Coventry Permanent Building Society v Jones [1951] 1 All E.R. 901, 903; Lloyds Bank v Rosset [1989] Ch. 350, 407; Abbey National Building Society v Cann [1991] A.C. 56, 89; Whale v Viasystems Ltd [2002] E.W.C.A. Civ 480, [73]-[74]; Hardy v Fowle [2007] E.W.H.C. 2423 (Ch), [102]; Scott v Southern Pacific Mortgages [2014] UKSC 52, [110].

${ }^{98}$ E.g., Fowkes $v$ Pascoe (1874-75) L.R. 10 Ch. App. 343, 352-353.

99 J Mee, 'Presumed resulting trusts, intention and declaration' [2014] C.L.J. 86, 110.

${ }^{100}$ E.g., Bull v Bull [1955] 1 Q.B. 234.

${ }^{101}$ As in City of London Building v Flegg [1988] A.C. 54, 61, where a declaration in a conveyance that land was conveyed to purchasers as beneficial joint tenants did not affect the position of contributors who were not parties to the conveyance. Contrast Goodman v Gallant [1986] 2 W.L.R. 236, where the contributor was a party to the conveyance and the declaration in that conveyance was therefore taken as conclusive evidence of her intentions, capable of rebutting the presumption of resulting trust.

${ }^{102}$ L Smith, The Law of Tracing (Oxford 1997) 6-17.
} 
did so on trust for himself, ${ }^{103}$ he would be entitled to any asset purchased using that money without needing to depend on a fresh grant in his favour by $\mathrm{Y}$ - either because he authorised this use of the money, and the law gives effects to his intentions as the settlor of the trust, or because the purchase represents an unauthorised substitution of his assets and the law protects him from the consequences of an unintended loss of his beneficial interest in the original asset. $^{104}$

By analogy, we might argue that an acquisition creditor obtains an interest in the purchased asset by an act of authorised substitution - it authorised the use of its money to buy that asset, on terms requiring that it be held subject to a security interest in its favour - and that this represents a mode of acquisition that is unaffected by limits on the purchaser's powers of grant. There are two difficulties in the way of such an argument. First, it is questionable whether the money used to complete the purchase can meaningfully be said to be the lender's money. The presumption of resulting trust does not usually operate in situations where money is paid by way of loan, ${ }^{105}$ even where the loan is motivated by the lender's knowledge that the borrower intends to use the loan money to acquire a specific asset. Secondly, even if an acquisition creditor does have a proprietary interest in money that she has lent, her security interest in the asset later purchased using that money requires justification. Since that interest seems to arise because of her consensual bargain with the purchaser, it seems odd to say that it does not depend on any grant by the purchaser but instead responds some inherent feature of her interest in the money. ${ }^{106}$

It is clear that merely lending money to facilitate the borrower's purchase of an asset does not give a lender any claim over the purchased asset. Where the lender intends the specific asset representing the loan money to be at the free disposal of the borrower, with the borrower merely having an obligation to repay the abstract amount of the debt, ${ }^{107}$ there is no room for the lender to argue that it has a sufficient interest in the loan money to permit it to lay claim to

\footnotetext{
${ }^{103}$ It is disputed whether X's payment to $\mathrm{Y}$ is presumed to be pursuant to a declaration of trust, an unexpressed intention that $\mathrm{Y}$ take as a trustee, or an intention that $\mathrm{Y}$ must not take for his own benefit: J Penner, 'Resulting Trusts and Unjust Enrichment: Three Controversies' in C Mitchell (ed), Resulting and Constructive Trusts (Oxford 2010) 237. Any of these characterisations justify X's claim to an interest in an asset acquired using the trust money, either because the substitution is authorised under the terms of the presumed declaration (or intention) or because it represents the traceable proceeds of an asset held on bare trust.

${ }^{104}$ A Nair, Claims to Traceable Proceeds: Law, Equity and the Control of Assets (Oxford 2018) 3.121-3.123.

${ }^{105}$ Dewar v Dewar [1975] 1 W.L.R. 1532; Re Sharpe [1980] 1 W.L.R. 219; Vajpayi v Yusaf [2003] EWHC

2339 (Ch). I am grateful to Professor William Swadling for drawing my attention to these cases and this objection.

${ }^{106}$ M Raczynska, The Law of Tracing in Commercial Transactions (Oxford 2018) [4.16]-[4.453].

107 cf. Foley v Hill (1848) 9 E.R. 1002, 1006-7.
} 
any substitutes. ${ }^{108}$ However, the position is different where the lender imposes conditions on the borrower's use of the very asset representing the loan money, ${ }^{109}$ rather than simply requiring repayment of the abstract amount borrowed. ${ }^{110}$ In the typical case where an institutional lender advances funds to a purchaser of land, on condition that it is to have a mortgage over the purchased title to the land, the loan money never comes under the control of the purchaser at all. ${ }^{111}$ Rather, payment will be made to a solicitor who acts for both purchaser and mortgagee and who holds the relevant bank account on trust for the lender ${ }^{112}$ up to the moment of the release of funds to the vendor. In Re Connolly Bros, where the lender's cheque was paid into the bank account of the purchaser rather than being handed directly to the vendor, the court was careful to note that this was only because the loan amount exceeded the purchase price by $£ 50$ and to trace from the bank account to the cash eventually paid to the vendor. ${ }^{113}$ In such cases, it is plausible that the lender does not part with the asset representing the loan money absolutely but rather on trust for itself, subject to a power to apply it for the purpose of completing the conveyance in the name of the purchaser. Until the payment to the vendor, therefore, the loan money genuinely is the lender's, in the sense that the asset representing the money is held on trust for it up to that moment.

The next question is whether it follows from this analysis that the lender obtains an immediate security interest in the purchased asset, of a kind that does not depend on any grant in its favour by the purchaser. A beneficiary under a trust will normally obtain a beneficial interest, not a security interest, in the product of any authorised substitution by the trustees. However, this is not a mandatory rule of law but simply the consequence of the terms of the trust in question; ${ }^{114}$ where the terms of the trust permit the trust asset to be exchanged for an asset that is held subject to a security interest in favour of the former beneficiary, the same principle justifies a different conclusion. ${ }^{115}$ It is more difficult to explain whether the right to the product of an authorised substitution represents, in some sense, an incident of the

\footnotetext{
108 cf. Kirkham v Peel (1880) 43 LT 171, discussed by Nair, Claims to Traceable Proceeds, at [6.12]-[6.15].

109 Twinsectra $v$ Yardley [2002] 2 A.C. 164, 185-187.

${ }^{110}$ Compare the looser intentions found to have accompanied the loans in Re Sharpe [1980] 1 W.L.R. 219,221

("I hoped that... he might be able to repay me") and Vajpayi v Yusaf [2003] EWHC 2339, [22] ("his obligation was to repay the money as and when he could.")

${ }^{111} R v$ Waya [2012] UKSC 51, [48]-[53].

${ }^{112}$ Boscawen v Bajwa [1996] 1 W.L.R. 328; Target Holdings v Redferns [1996] A.C. 421; AIB Group (UK) plc $v$ Redler [2014] UKSC 58; Lloyds TSB Bank Plc v Markandan \& Uddin [2012] EWCA Civ 65.

113 [1912] 2 Ch. 25, 31.

114 D Nolan, 'Property in a Fund' (2004) 120 L.Q.R. 108, 115.

115 A Televantos, 'Overreaching and Trusts of Land' (2018) 78 C.L.J 516, 518-519.
} 
beneficiary's original right under the trust. ${ }^{116}$ While there is a tradition in the case law of coupling claims to substitute assets with claims based on such events as the mixture of goods or accretions to land, ${ }^{117}$ there are also important differences between substitution and these events. As Raczynska has explained, when an accretion occurs, it becomes impossible to separate legal title to the chattel from title to the land and the legal system is obliged to make an allocative decision between the parties. ${ }^{118}$ By contrast, when a substitution occurs, there is no such necessity and instead some positive justification must be found for treating the beneficiary as entitled to the substitute asset. In the case of an authorised substitution, the most obvious justification is consent: the settlor has directed the trustee to hold substitute assets on the terms of the trust, and the law simply gives effect to the trustee's consent to those terms when it recognises the beneficiary's claim to a substitute asset.

However, it does not follow that the beneficiary's entitlement to a substitute asset is best explained as a right arising in response to a grant by the trustee as present owner of that very asset. When trustees obtain a fresh asset in their exercise of the powers conferred upon them by the terms of the trust, no new trust arises in relation to the new assets ${ }^{119}$ and no fresh declaration of trust is required on the part of the trustees. ${ }^{120}$ As Penner argues, ${ }^{121}$ this strongly indicates that the consent that does the explanatory work in such cases is the consent of the settlor, qua owner of the original trust asset, rather than the consent of the trustee, qua owner of the substitute. Beneficiaries' rights to substitute assets are derivative in the sense that they arise in response to the deliberate choice of the owner of an asset. However, the owner whose choice matters in this context is the owner of the original trust asset, who has required that the trustees' powers of disposition over the original asset are to be exercised on particular terms; $;^{122}$ the law takes no interest in the intentions of the trustee or of the seller of the substitute asset, except insofar as the terms of the trust render those intentions relevant. ${ }^{123} \mathrm{We}$ can therefore say

\footnotetext{
${ }^{116}$ Divergent views on this question are expressed by J Penner, 'Duty and Liability in Respect of Funds' in J Lowry and M Loukas (eds), Commercial Law: Perspectives and Practice (London 2006) 207, D Nolan, 'Property in a Fund' (2004) 120 L.Q.R. 108, and M Raczynska, The Law of Tracing in Commercial Transactions, [4.16]-[4.453].

${ }^{117}$ E.g., Scott v Surman (1742- 3) 125 ER 1235, 1237-1248; Taylor v Plumer (1815) 105 E.R. 721, 725-726; Buhr v Barclays Bank [2001] EWCA Civ 1223, [39]-[44].

${ }^{118}$ Raczynska, The Law of Tracing in Commercial Transactions [4.26]-[4.27].

${ }^{119}$ See L Tucker et al, Lewin on Trusts (20 th edn, London 2020) [3-054] to [3-064].

${ }^{120}$ D Fox, 'Overreaching' in P Birks and A Pretto-Sakmann (eds), Breach of Trust (Oxford 2002) 95, 96; D

Nolan, 'Property in a Fund' (2004) 120 L.Q.R. 108, 114.

${ }^{121}$ J Penner, 'The (True) Nature of a Beneficiary's Equitable Proprietary Interest under a Trust' (2014) 27 Can. J. L. \& Jurisprudence 473, 493.

122 Penner, 'The True Nature' 476-484.

${ }^{123}$ Nair, Claims to Traceable Proceeds, [3.61] to [3.66].
} 
that trust beneficiaries' claims to substitute assets represent an incident of their rights under the original trust, in the sense that these claims are fully justified by the law's respect for the decision of the settlor as owner of the original assets, without the need to invoke any independent decision by an owner of the substitute assets. Applying this analysis to the case of the acquisition creditor, then, we can say that the creditor's security interest over the purchased asset reflects the terms of the trust on which the loan money was advanced and does not, therefore, depend on any separate grant in its favour by the purchaser. ${ }^{124}$

Nothing in this analysis is unique to real property, and so it could equally apply for the benefit of a creditor who funds the acquisition of personal property. ${ }^{125}$ The only requirement is that, as is perhaps more common in the case of loans to purchase real property, the lender must make its advance on terms that plainly involve a trust of the original loan money. To this extent, this analysis implies a broader range for the principle than has sometimes been asserted. ${ }^{126}$ At the same time, however, it also implies a number of limits to the acquisition creditor's claims.

First, the argument only makes sense in equity. ${ }^{127}$ In cases involving the purchase of land, lenders will normally authorise their solicitor-trustees to release funds only on condition that the borrower has agreed to execute a legal mortgage over the purchased estate in land. Nevertheless, they cannot argue that such a mortgage has arisen, automatically, just as a consequence of the trust of the money and without the need for a separate grant by a holder of legal title to the land. A charge by way of legal mortgage, which includes a right to possession of land, ${ }^{128}$ can only be conferred by a person who has a legal title to that land or is otherwise authorised to deal with a legal title; formality ${ }^{129}$ and registration ${ }^{130}$ requirements must also be met before any such right can arise. The argument that the creditor's rights operate automatically upon the purchaser's acquisition of legal title can mean only that the purchaser

\footnotetext{
${ }^{124}$ This may also explain why, in cases where the lender's money is used to pay off a debt owed to another creditor without its consent, subrogation to the rights of that creditor is available without the need for a separate agreement: see Menelaou v Bank of Cyprus Plc [2016] A.C. 176, [111]-[117], [133]-[140] (Lord Carnwath $\mathrm{SJC})$.

125 cf. Kerakoose v Brooks.

${ }^{126}$ R Boadle, 'A purchase money security interest in UK Law?' [2014] LMCLQ 76.

127 There may be circumstances where an authorised substitution by an agent gives a principal a common law title to the purchased asset: B Geva, 'Authority of Sale and Privity of Contract: The Proprietary Basis of the Right to the Proceeds of Sale at Common Law' (1980) 25 McGill Law Journal 32. However, these arguments are only relevant where legal title to the original asset remains vested in the principal and are not engaged where that title is transferred to a trustee.

${ }^{128}$ Law of Property Act 1925, s. 87.

${ }^{129}$ Law of Property Act 1925, s. 52.

${ }^{130}$ Land Registration Act 2002, s. 27(2)(f).
} 
is bound, in equity, to hold subject to the terms prescribed by the original trust of the money; it cannot mean that a legal mortgage arises by operation of law, without any grant by the purchaser or without compliance with the statutory formalities for the grant of such rights. Secondly, the argument from substitution only holds to the extent that the purchased asset is in fact acquired with the trust money. It is, therefore, contingent on tracing; for the justification based on the creditor's control over its money to apply, the very funds used to buy the substitute must represent the trust money. Thirdly, in cases involving multiple contributors to acquisition, the normal rules governing the apportionment of claims between innocent contributors to a mixed substitution apply. ${ }^{131}$ Thus, as against any third party who has also contributed to acquisition on terms that entitle her to a share of the asset, the creditor's equitable interest in the purchased asset is limited to a share proportionate to its actual contribution.

\section{Substitution and the Modern Cases: Law, Equity, and Land Registration}

This account of the claims of an acquisition creditor can readily be squared with the older case law, up to Re Connolly Bros. In those cases, both parties to the dispute had a purely financial stake in the purchased asset, which meant that they agreed that it ought to be sold. The task of the court was only to determine whether acquisition creditors could insist on being paid out of the proceeds of sale in preference to other creditors and we have seen that they did this-in accordance with the limits set out above - only in proportion to the lender's actual contribution to acquisition.

In the modern cases, mortgagees who had funded the acquisition of titles to land sought to assert their security against residential occupiers of that land, such as tenants ${ }^{132}$ and trust beneficiaries, ${ }^{133}$ and succeeded in obtaining orders for possession against these occupiers. These claims cannot have depended, as in the earlier cases, on the assertion of some kind of equitable lien or charge ${ }^{134}$ that entitled the creditor to keep or recover a specified share of the proceeds of sale; it must have been the creditor's legal mortgage that bound the occupier, and entitled it to possession. Further, in Cann itself, the occupying beneficiary was argued to be a contributor to acquisition, who had authorised the use of trust money to buy the disputed

\footnotetext{
${ }^{131}$ Foskett v McKeown [2002] 1 A.C. 102, 132.

${ }^{132}$ As in Coventry Permanent Building Society v Jones [1951] 1 All E.R. 901, Woolwich Equitable Building Society v Marshall [1952] Ch. 1, Universal Permanent Building Society v Cooke [1952] Ch. 95, Mornington Permanent BS v Kenway [1953] Ch. 382, Church of England Building Society v Piskor [1954] 1 Ch. 553, Grace Rymer Investments Ltd $v$ Waite [1958] 1 Ch. 831.

${ }^{133}$ As in Lloyds Bank plc v Rosset [1989] Ch. 350 (CA) and Cann.

134 cf. Allen v Longstaffe (1887) 37 Ch. D. 48, 50.
} 
leasehold title on condition that it was to be held on trust for her. ${ }^{135}$ If the creditor's rights depend on a substitution, capable of creating only an equitable interest reflecting its actual contribution to acquisition, both these outcomes require explanation. Why should the mortgagee have priority at law, and why was there no apportionment solution in Cann?

The answers to these questions flow from the intersection between the Re Connolly Bros principle and general rules of priority. In holding that the principle was not confined to equity, but could confer priority on the mortgagee at law, ${ }^{136}$ Lord Jauncey explained that this was because the equitable interest of the lender had been "clothed with the legal estate". ${ }^{137}$ This suggests that the lender's equitable interest in the purchased asset, arising in response to its contribution to acquisition, was not-as Piskor might suggest-simply destroyed by its acquisition of a legal mortgage. Where an equitable right-holder obtains a legal estate, that legal estate will share the priority of the underlying equitable interest, unless the legal estateholder has done something to displace this priority. ${ }^{138}$ This is sufficient to explain why the legal mortgage binds any post-acquisition grantee of the purchaser: the equitable interest of the lender binds such parties, and the lender will have done nothing to surrender its priority upon acquiring the legal estate. The alternative view, which suggests that the equitable interest of the lender simply merges into the legal mortgage and is lost, ${ }^{139}$ is inconsistent with the general principle that merger in equity does not take place unless the parties intend it to do so. ${ }^{140}$ This argument is not, however, available in the same form against a right-holder whose own interest arises in response to her contribution to acquisition, as in cases involving purchase-money resulting trusts: such a right-holder is no more a post-acquisition grantee of the purchaser than the creditor itself. Like the creditor, she too will have an equitable interest in the purchased asset that is proportionate to her contribution to acquisition. In order for the acquisition creditor to argue that it is not bound by her equitable interest, based on contribution, it is not sufficient to show that it has done nothing to surrender the priority of its own contribution-based equitable interest. It will need to invoke a freestanding defence, which displaces the obligation to take account of the interests of the co-contributor that it would otherwise owe.

Two such defences were, in fact, available to the lender in Cann. In registered land, the creditor's acquisition of a registered legal mortgage, for value, will give it priority over an

\footnotetext{
135 [1991] 1 A.C. 56, 66-67.

136 Overruling Church of England Building Society v Piskor [1954] 1 Ch. 553.

137 [1991] 1 A.C. 56, 101.

138 cf. Taylor v Russell [1892] A.C. 244.

139 cf. Capital Finance Co Ltd v Stokes [1969] 1 Ch. 261.

${ }^{140}$ Capital and Counties Bank v Rhodes [1903] 1 Ch. 631.
} 
equitable right-holder who is not in actual occupation of the land at the date of completion ${ }^{141}$ of the charge; in Cann, it was held that Mrs Cann was not in actual occupation at that date. ${ }^{142}$ Secondly, where the co-contributor is aware that mortgage finance is necessary to complete the purchase, it will sometimes be found that she has authorised the purchaser to raise the money on mortgage on terms that postpone the priority of her own rights; this may be so where she has implicitly agreed to such a postponement or where she has given the purchaser ostensible authority to grant the mortgage free from her interests. ${ }^{143}$ As was held in the lower courts, ${ }^{144}$ this defence too was available to the lender in Cann. The case is not, therefore, authority precluding the availability of an apportionment solution in the absence of these defences. For example, in registered land, the creditor would lack a separate defence in a case where the cocontributor has not implicitly consented to a postponement of her rights and where it either fails to obtain registration of its charge ${ }^{145}$ or fails to discover her actual occupation of the land prior to completion. In relation to personal property, the creditor would lack a separate defence in a case where it failed to obtain a legal interest in the property or had actual or constructive notice of the co-contributor's interest. ${ }^{146}$

\section{CONCLUSIONS}

I have argued that the principle favouring acquisition creditors is ultimately about protecting the creditor's title to its money, giving it a claim to substitute assets acquired using that money. This outcome has some intuitive appeal, on the basis that a grantee of a purchaser should not be allowed to take free of the interests of the lender whose financial contribution made the purchaser's acquisition of title possible in the first place. However, this intuition has its limits. If the principle is extended to confer priority on the acquisition creditor against all possible rivals - including those who have themselves put money into the acquisition of the asset-it becomes singularly unattractive. I have shown that English law does not compel us to this unattractive conclusion; putting the principle in the context of its historical origins shows that

\footnotetext{
${ }^{141}$ Land Registration Act 2002, s. 29(1) and sch. 3, para. 2.

142 [1991] 1 A.C. 56, 101.

143 Ali v Dinc [2020] EWHC 3055, [337].

144 (1989) 57 P. \& C.R. 381, 391.

${ }^{145}$ E.g., Barclays Bank plc v Zaroovabli [1997] Ch. 321.

146 cf. the Universal Commercial Code Article 9, [9-322].
} 
it has a more modest and persuasive reach. 